6. Удвоенные гаплоиды ячменя и их использование в генетико-селекционных исследованиях / Я.В. Мишуткина, Я.Б. Нескородов, М.Г. Новокрещенова и др. // Современные проблемы науки и образования. - 2013. - № 5. - С. 476-486.

7. Kasha, K.J. High frequency haploid production in barley (H. vulgare L.) / K.J. Kasha, K.N. Kao // Nature. - 1970. - Vol. 225. - P. 874-876.

8. Clapham, D. Haploid Hordeum plants from anthers in vitro / D. Clapham // Z Pflanzenzücht. - 1973. - Vol. 69. - P. 142-155.

9. San Noeum, L.H. Haploïdes Hordeum vulgare L. par culture in vitro d'ovaires non fecondés / L.H. San Noeum // Ann Amélior Plant. - 1976. - Vol. 26. - P. 751-783.

10. Culture conditions for induction of green plants from barley microspores by anther culture methods / K.N. Kao, M. Saleem, S. Abrams et al. // Plant Cell Reports. - 1991. Vol. 9. - P. 595-601.

11. ФГБУ Госсорткомиссия [Электронный ресурс]. - Режим доступа: http://reestr.gossortrf.ru/, свободный - (28.02.2020)

DOI $10.18699 / \mathrm{GPB} 2020-100$

\title{
Отдаленная гибридизация как метод создания 000-форм ярового рапса (Brassica Napus L.)
}

Потапов Д.А., к.с.-х.н., в.н.с.

Сибирский федеральный научный центр агробиотехнологий РАН, Новосибирск, Россия.

e-mail:d_potapov@ngs.ru

С изелью создания желтосемянного материала ярового рапса были проведены скрещчивания между видами родов Brassica u Sinapis. B качестве исходного материала использовали инбреднье линии B. пария, желтосемянныле сорта B. campestris, B. juncea u S. alba.Уcnех отдаленных скрещчиваний в значительной степени определялся родственными связями видов рода Brassica согласно схеме Nagaharu U. B результате селекционной проработки этого материала созданы формы с желтой окраской оболочки семян для выведения сортов ярового рапса в условиях Западной Сибири.

Ключевые слова: селекичя, яровой рапс, окраска оболочки семян, 000формил.

\section{Interspecific hybridization as a method for development of yellow-seeded Brassica napus $\mathrm{L}$.}

Potapov D.A., Siberian Federal Scientific Centre of Agro-BioTechnologies of the Russian Academy of Sciences; Novosibirsk, Russian Federation.

*e-mail:d_potapov@ngs.ru

Crosses between species of the genera Brassica and Sinapis were carried out to obtain a yellow-seed material of Brassica napus. Inbred lines of B. napus, 
yellow-seeded cultivars of B. campestris, B. juncea, and S. alba were used as initial material. The success of interspecific crosses was determined by the relationship of species of the genus Brassica according to the triangle of U. Yellow-seed forms of B. napus obtained as a result of breeding study of this material are involved in developing of new cultivars under condition of Western Siberia.

Keywords: breeding, Brassica napus, seed color, 000-forms.

Отдаленная гибридизация в роде Brassica является эффективным методом создания новых форм, обладающих хозяйственно важными признаками и свойствами [1]. С использованием этой процедуры был создан первый отечественный безэруковый низколиноленовый сорт ярового рапса Кубанский. Более 60 \% сортов, выведенных в Японии, США и Канаде, получены в результате межвидовой гибридизации. Этот метод является неотъемлемым элементом селекционных программ, связанных с созданием ярового рапса с желтой окраской оболочки семян потому, что в пределах этого вида нет желтосемянных форм $[1,2]$. Наши исследования по получению ярового рапса 000-типа привели к созданию перспективных селекционных форм, окраска оболочки семян которых проявлялась с некоторой изменчивостью [3].

С целью повышения генетической стабильности признака желтой окраски оболочки семян и улучшения некоторых хозяйственно полезных признаков у созданных светлосемянных форм ярового рапса в 2007 г. было проведено 62 комбинации скрещиваний между видами родов Brassica и Sinapis. B. napus был представлен растениями инбредных линий, дифференцированных по основным морфобиологическим и хозяйственным признакам и свойствам; B. campestris - сортами Янтарная, Восточная, Золотистая; B. juncea Славянка, Росинка, Л.№264; и S. alba - Радуга, ВНИИМК-518, Л.№292

Из 3560 опыленных цветков образовали стручки и завязали семена 1116 цветков, что составило 31 \%. Всего получено 21959 гибридных семян $\mathrm{F}_{1}$. Успех отдаленных скрещиваний в значительной степени определялся родственными связями видов рода Brassica согласно схеме Nagaharu U [4]. Так, наибольшее количество выполненных семян в стручке получено в комбинациях B. napus х B. campestris (табл. 1).

Таблица 1 - Результаты отдаленных скрещиваний видов семейства Brassicaceae

\begin{tabular}{|c|c|c|c|}
\hline \multicolumn{2}{|c|}{ Комбинация скрещиваний } & \multirow{2}{*}{$\begin{array}{c}\text { Завязавшихся } \\
\text { стручков, \% }\end{array}$} & \multirow{2}{*}{$\begin{array}{c}\text { Выполненных } \\
\text { семян, \% }\end{array}$} \\
\hline q & $\overline{0}$ & & \\
\hline$\frac{1}{1}$ & 2 & 3 & 4 \\
\hline B. napus & B. campestris & 38 & 61 \\
\hline -"- & B. juncea & 30 & 8 \\
\hline -"- & S. alba & 9 & 25 \\
\hline -"- & B. napus & 67 & 75 \\
\hline
\end{tabular}




\begin{tabular}{|c|l|l|c|}
\hline $\mathbf{1}$ & \multicolumn{1}{|c|}{$\mathbf{2}$} & $\mathbf{3}$ & $\mathbf{4}$ \\
\hline B. campestris & B. napus & 32 & 24 \\
\hline -"- & B. juncea & 36 & 1 \\
\hline -"- & S. alba & 32 & 55 \\
\hline B. juncea & B. napus & 63 & 13 \\
\hline -"- & B. campestris & 24 & 1 \\
\hline S. alba & B. napus & 14 & \\
\hline
\end{tabular}

Наиболее успешные скрещивания были в тех комбинациях, где в качестве матери использовался высокохромосомный вид. При скрещивании $B$. napus и B. juncea наблюдался высокий процент завязывания стручков, однако практически все гибридные семена были мелкими и щуплыми. В обратных скрещиваниях - более половины гибридных семян были выполненными (табл. 1).

При скрещивании B. napus и B. campestris, где в качестве отцовской формы была взята сурепица, не было значительных различий по доле завязавшихся стручков и доле выполненных семян, хотя процент завязавшихся стручков был несколько выше при опылении пыльцой сорта Золотистая. Однако, если B. campestris использовалась как материнский родитель, то при завязывании стручков наблюдались значительные различия. Так, при скрещивании сорта Золотистая с $B$. napus завязалось 48 \% опыленных цветков, а у сорта Восточная - всего 7, т.е. почти в 7 раз меньше. Видимо сорт Золотистая обладает более широкой генетической базой, что позволяет ему наиболее успешно скрещиваться с рапсом.

Созданные отдаленные гибриды со светлой окраской оболочки семян, были включены в селекционный процесс для доработки методом инбридинга в сочетании с отборами.

Селекционное изучение этих форм, подвергнутых давлению отбора при строгом самоопылении растений, в сравнении с черносемянными образцами показало, что среди образцов с желтой окраской оболочки семян можно отобрать линии, существенно превышающие последние по ряду хозяйственно важных признаков $[3,5]$. Подтверждением этому служат результаты изучения, полученные на созданных нами желтосемянных формах ярового рапса в конкурсных питомниках в сравнении с черносемянным сортом СибНИИК 198, включенным в Госреестр, в том числе и по Западно-Сибирскому региону. В таблице 2 приведена характеристика наиболее стабильного по окраске оболочке семян желтосемянного селекционного номера СНК-32. Этот номер достоверно превышал сорт СибНИИК 198 по урожайности семян, зеленой массы, и содержанию сырого жира в семенах. 
Таблища 2 - Характеристика ярового рапса в питомнике конкурсного сортоиспытания 2019 г.

\begin{tabular}{|l|c|c|c|c|c|c|}
\hline \multirow{2}{*}{ Образец } & \multicolumn{4}{|c|}{ Урожайность, ц/га } & \multicolumn{2}{c|}{$\begin{array}{c}\text { одержание жира } \\
\text { в семенах }\end{array}$} \\
\cline { 2 - 8 } & семян & \% к ст. & $\begin{array}{c}\text { зеленой } \\
\text { массы }\end{array}$ & \% к ст. & $\%$ & \pm к ст. \\
\hline СНК-32 & 20,6 & $125^{*}$ & 338 & $114^{*}$ & 45,0 & $2,7 *$ \\
\hline СибНИИК 198, ст. & 16,5 & 100 & 297 & 100 & 42,3 & 0 \\
\hline
\end{tabular}

* - значимо на 5 \%-ном уровне, ст. - стандарт

Таким образом, с использованием метода отдаленной гибридизации нами создан исходный материал для селекции сортов ярового рапса с желтой окраской оболочки семян в условиях Западной Сибири.

\section{Список литературы}

1. Осипова Г.М., Потапов Д.А. Рапс (Особенности биологии, селекция в условиях Сибири и экологические аспекты использования) / Россельхозакадемия. Сиб. отдние. - Новосибирск, 2009. - 132 с.

2. Somers D., Rakow G., Prabhu V., Friesen K. Identification of a major gene and RAPD markers for yellow seed coat colour in Brassica napus // Genome. - 2001. - V. 44, №6. - P. 1077-1082.

3. Potapov D.A., Osipova G.M. Approaches to the efficient use and to increase the diversity of genetic resources for the development of prospective breeding materials of yellow-seeded Brassica napus L. for conditions of Siberia // Oilseed crops. - 2005. - V. 26. №2. - P. 335-348.

4. U N. Genome analysis in Brassica with special reference to the experimental formation of B. napus and peculiar mode of fertilization. // Japanese J. Bot. - 1935. - N. 7. P. $398-452$.

5. Осипова Г.М., Потапов Д.А. Гибридологический анализ окраски оболочки семян у ярового рапса // Сиб. вестник с.-Х. науки. - 2015. - № 4. - С. 32-38.

DOI 10.18699/GPB2020-101

\section{Генофонд национального банка семян полевых культур Беларуси и его использование в селекции}

Привалов Ф.И.д.с.-х.н., генеральный директор; Гриб. С.И., д.с.-х.н., г.н.с.; Матыс И.С., к.с.-х.н., зав. отделом генетических ресурсов растений. РУП «Научно-практический центр НАН Беларуси по земледелию», Жодино, Республика Беларусь.

e-mail: belgenbank@mail.ru

В статье освещены вопросы создания и формирования Националь- 